industry, wide learning, and earnest devotion to the pursuit of truth, he has rendered exceedingly great services to the cause of knowledge by the stimulus which he has given to historical and literary studies in Southern India.

L. D. BarnetT.

\title{
J. Estlin Carpenter
}

By the death of J. Estlin Carpenter, D.Litt. and D.D. (Oxford), Hon. D.D. (Glasgow), D.Theol. (Jena and Geneva), which occurred on 2nd June, the Society loses a distinguished member, and Oxford society a highly respected and dearly loved figure. Dr. Carpenter, who was born in 1844, after holding ministerial appointments in the Unitarian community at Clifton and Leeds, accepted a lectureship at Manchester College in 1875, and was Principal of that institution, by then established in Oxford, from 1906 to 1915. His interest lay chiefly in natural and comparative religion, of which he was appointed to the Wilde Lectureship at Oxford in 1914. He took a prominent part in organizing the Third International Congress for the History of Religions which met at Oxford, 15th to 18th September, 1908, and greatly contributed to its success. His interest in these matters led him to study various Oriental languages and indeed profoundly. He wrote on Pentateuchal Criticism, of which he is by some authors (e.g. Mr. Harold Wiener) treated as a leading exponent; he collaborated with Professor Rhys Davids in editing Buddhistic texts and was one of the recognized authorities on Pali ; he wrote on the Synoptic problem, and on Theism in Mediaeval India. He translated Tiele's standard work on the History of Religion, and edited the translation of Ewald's History of Israel, a work which is now almost forgotten, but which exercised great influence in its time, though probably rated at its true value by Bishop Colenso.

As principal of Manchester College he won the warm affection and admiration of his students, many of whom have acquired fame. He extended its hospitality to representatives of 
many systems and ideas; thus, when 'Abd al-Bahā, the then head of the Bahā'ĩ community, visited Oxford, his address was delivered in this building. Till almost the end of his life his physical and intellectual vigour were unimpaired.

D. S. M.

\section{Ya'kub Sarruf}

On Sunday, 10th July, literary and scientific circles in Cairo were grieved to learn of the death after a short illness of Dr. Y. Șarrūf, editor of the Muktataf, by far the most esteemed as well as the oldest of the Arabic periodicals, and a member of this Society since 1904. The esteem wherein he was held in Cairo appears in the account of his funeral, ${ }^{1}$ which was attended by Cabinet ministers and distinguished members of all professions, and the messages sent to his family from King Fuad, at that time in London, and other prominent political personages, learned bodies, etc. His death followed by less than a year and a quarter the celebrations of the Jubilee of the Muktataf, which were initiated by the popular authoress, Mlle May, and of which the proceedings are recorded in the "Golden Volume" presented to subscribers to that magazine. A fairly lengthy biography of him is given by Elias Zakhoura in his work on the Celebrities of Egypt, dated $1897,{ }^{2}$ from which the following details are taken.

Șarrūf was born 18th July, 1852, in the Lebanon, and studied at the American University of Beyrut, where he took a B.Sc. in 1870. For the next two years he was employed as lecturer in Arabic to the American mission in Sidon, after which he was principal for a year of the College established by the Americans in the Syrian Tripoli. He then returned to Beyrut as Professor of Mathematics and Natural Science. "There was no experiment mentioned in the text-books of

1 See the Mokattam of 13th July.

2

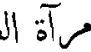

